\title{
Culture in a Clash of Opposing Forces in Macbeth
}

\author{
Hossein Fathi Pishosta
}

Member of the Academic Board of Rafsanjan Vali-e-Asr University, Rafsanjan, Kerman (Iran

S. Habib Mousavi

PhD Candidate, English Literature; University of Tehran; Correspondence: h.fathi@vru.ac.ir

\section{Doi:10.5901/mjss.2016.v7n1s1p293}

\begin{abstract}
Similar to scores of other critics of culture, Raymond Williams, as one of the founders of cultural materialism, maintains that the phenomenon of 'culture' is not something fixed and given. It is, indeed, in his belief, the outcome of a permanent struggle between 'dominant', 'residual' and 'emergent' elements. Hence, culture is a wholly dynamic phenomenon. The current paper conducts a survey into the crusade of such currents in Shakespeare's masterpiece, Macbeth. Consequently, we see, as Williams believes, that culture is the battleground of the aforementioned elements. In the world of Macbeth, 'divine kingship' as the dominant cultural from gives way to the 'contractual theory' for a period of time to be changed with the 'residual' elements of the previous generation which were active, not passive, though without, or at most with limited authority. The point is that the residual form of the previous generation, which was the dominant form before, is now forced to break with its regulations in order to get dominant once more. Macbeth ventures to depict a territory where the dominant element of the culture becomes defeated in an affray with the residual element. Shakespeare's Macbeth anticipates the time when 'contractual theory' became strident and absolute as the Stuart monarchy lost more and more of its power and influence in the 1630s.
\end{abstract}

Keywords: Macbeth, Culture, Dominant, Residual, Emergent, Divine kingship, Contractual theory

\section{Introduction}

The theater of William Shakespeare has given rise to diverse critical interpretations and it still exercises an extraordinary influence on its audience. This is, in part, due to the fact that Shakespeare's plays manage to typify the zeitgeist of various facets of his age. They have especially opened up new perspectives on discussions of culture and its interaction with other social and political elements during the life of the playwright. Hence, this study is an attempt to illuminate the cultural resonance of Shakespeare's play Macbeth and its political implications. In this regard, it addresses Shakespeare's great tragedy by drawing on Raymond William's notion of culture as elaborated in his Marxism and Literature (1977). It investigates, in particular, the significant role of cultural elements in shaping the relations of power as mirrored in the play. Such a reading aims at opening a new avenue of research to the multifarious discussions of the play and highlights the idea that Shakespeare was not a mere neutral observer of the political and cultural scene of his age.

The works of the cultural materialist Raymond Williams (1921-1988) are a significant contribution to the critique of culture and its manifestation in arts. In his attentive reading of Shakespeare's theater, Williams finds one of the sources of his concept of culture and its clash of opposing elements. The notion of culture for Williams enjoys a dynamic quality; his theoretical ideas of 'dominant', 'residual' and 'emergent' elements within a culture are based upon a certain premise in the first place: society is in a non-stop condition of cultural mutation. Hence, society is posited as a struggle between the dominant, residual, and emergent ideological currents. Williams tries to separate what he calls 'residual' from the 'archaic' sense of it; however, as he himself notes, "in practice these are often very difficult to distinguish" (p. 122). He states that every culture is comprised of some elements of the past. Residual, associated with archaic, according to Williams, is comprised of the elements of the past, which are prone to be observed, examined, and maybe consciously 'revived' (ibid). Williams states that the "residual... has been effectively formed in the past, but it is still active in the cultural process, not only and often not at all as an element of the past, but as an effective element of the present" (ibid). He argues that "a residual cultural element is usually at some distance from the effective dominant culture, but some part of it, some version of it" (p. 123). Meanings and values that cannot be practiced and substantiated through the dominant culture, are doomed to be practiced and substantiated on the basis of the residue.

The notion of culture is also for Williams suggestive of the condition of literature. Similar to literature, when seen in 
the broad context of historical development, this notion has been both in definition and comprehension subject to multiple and even contradictory changes of meaning (p. 13); hence, citing Herder, it is necessary, for Williams, to use the term in the plural, and "speak of 'cultures' rather than 'culture', so as to acknowledge variability, and within any culture to recognize the complexity and variability of its shaping forces." (P. 17) He argues against a 'static' view of any cultural process and, in fact, for him, the complexity of a culture is to be found "not only in its variable processes and their social definitions-- traditions, institutions, and formations- but also in the dynamic interrelations, at every point in the process, of historically varied and variable elements" (p. 121).

Addressing the internal dynamic relations of any actual cultural process, Williams classifies these relations into 'residual', 'emergent' and 'dominant' categories. By the residual he means something different from the 'archaic' though in practice it is difficult to differentiate the two. He calls the 'archaic' that which is wholly recognized as an element of the past and may be observed, examined, or even on occasions consciously 'revived', in a deliberately specializing way. What Williams means by the 'residual' is very different. The residual has been effectively formed in the past, but it is still active in a cultural process, "not only and often not at all as an element of the past, but as an effective element of the present." (p. 122) Thus, for him, "certain experiences, meanings, and values which cannot be expressed or substantially verified in terms of the dominant culture, are nevertheless lived and practiced on the basis of the residue --cultural as well as social-- of some previous social and cultural institution or formation." (ibid) The residual may have an alternative or oppositional relation to the dominant culture but may also be incorporated into it through processes of "reinterpretation, dilution, projection, discriminating inclusion and exclusion." (p. 123) According to Williams, formations that have an "emergent' relationship to the dominant culture are not only those "new meanings and values, new practices, new relationships and kinds of relationship" which are continually being created, but also those which are "substantially alternative or oppositional to it: emergent in the strict sense, rather than merely novel." (ibid) Indeed, a variety of new experiences and events emerge in a dominant culture. For him, a new cultural practice is not an isolated one, and to "the degree that it emerges, and especially to the degree that it is oppositional rather than alternative", the process of the attempted incorporation by the dominant culture significantly begins (p. 124). Notwithstanding, as he concludes, "no mode of production and therefore no dominant social order and therefore no dominant culture ever in reality includes or exhausts all human practices, human energy, and human intention" (p. 125).

'Emergent' for Williams suggests that "new meanings and values, new practices, new relationships and kinds of relationship are continually being created" ( $p .123)$, but it makes it quite formidable to distinguish between those which are really new components of the dominant culture or those which are fundamentally radical and opposed to it. Within this system, the definition of the 'emergent' can be made by being completely versed in the whole aspects of the dominant culture. In the developing phases of a dominant culture, there are some tendencies to revive those values created in the past which "the dominant culture neglects, undervalues, opposes, represses, or even cannot recognize" (p.124). What becomes self-evident here is that "...no mode of production and therefore no dominant social order and therefore no dominant culture ever in reality includes or exhausts all human practices, human energy, and human intention" (p.125). Therefore the dominant culture is completely selective in its selection and or abolition of practices. Some specific practices are favored, but some others banned. The new opposing elements would 'emerge' time by time. Some of them would strengthen to the point that will overcome the boundaries of dominant order (culture) and actually replace them. The new dominant culture would deal with its residual cultures to be replaced by them some other time. Williams bears this circular process in mind as the truth and reality of every culture.

\section{Elements of Culture in Macbeth}

These elements of culture, already touched upon, struggle a great deal in Macbeth, the shortest but the goriest tragedy of Shakespeare, the world monarch of drama, which was probably written in 1606, almost 3 years after the death of the honored queen of England, Elizabeth I, and 3 years from the succession of James I of Scotland. Macbeth is one of the greatest plays of William Shakespeare. Concerning the play, Samuel Johnson (as cited in Bloom \& Marson, 2008, p. 51) says:

This play is deservedly celebrated for the propriety of its fictions, and solemnity, grandeur, and variety of its action; but it has no nice discriminations of character, the events are too great to admit the influence of particular dispositions, and the course of the action necessarily determines the conduct of the agents. The danger of ambition is well described; and I know not whether it may not be said in defense of some parts which now seem improbable, that, in Shakespeare's time, it was necessary to warn credulity against vain and illusive predictions. 
The current study focuses merely on the idea of kingship within the world of the play. During various eras down the history lane kings have been mostly supposed, or supposed themselves to be, divine and as an incarnation, manifestation, mediator, or agent of the sacred. This divine-right theory of kingship signifies a political and religious creed of royal and political authority. It states that a sovereign is not subject to any earthly power, and secures his license to rule straight from the will of God. The Crown is thus not constrained by the desire of his subjects. Based on such belief, even the inequitable kings are not to be judged by anyone except the Almighty. This code of belief suggests that any venture to dethrone the royal personage or to limit his authority is against the will of God and signals a profane act. It is ordinarily exhibited in the phrase 'by the Grace of God,' ascribed to the titles of a king on the throne.

The notion of divine right of kings is well mirrored in Renaissance drama of the Tudor and Jacobean periods; according to Hattaway (2002) it had really been brought into being by Henry VIII's claim to be entitled to appoint bishops in place of the Pope and was generated by the presence within one political system of both secular and religious powers (p. 110). In his comment on the sacred aspects of Tudor kingship and the mystical symbolism surrounding the anointed monarch in the 1590's Hadfield (2004) observes that a "whole array of potent symbols was created by artists, poets and other propagandists who were patronized by the crown, showing that the king or queen was the chosen deputy of God on earth" (p. 42). The idea finds also its expression in the speech of King James I (1566-1625) of England to the parliament in 1610 who (as cited in Dutton \& Howard, 2003, p. 125) asserted that "kings are justly called gods."

While kings are up there in the power hierarchy, the narratives they subscribe to are impossible to challenge or disbelieve. Kings and the entourage determine the dominant culture through their grand narratives. Hence, it emerges crystal-clear that the dominant culture gives credence to its own grand narratives. These grand narratives all-together establish a redline out of which no one is allowed to step. Therefore, an ideological framework advances into the realm of being which bases the dominant culture. This framework shall maintain; else, the rebels would taste the bitter torments of the kings and consequently gods.

This theoretical concept, already well established, bear out during the sixteenth century when Henry VIII broke with Rome and established church of England under his own name. This divine identity attached to the kings made any resistance to their earthly supremacy nothing but treason, and as mounting a rebellion against God Himself, a mere act of infidelity and preordained to defeat. A certain formulation that contributed to account for absolute monarchical authority and infallibility was the doctrine of King's Two Bodies. This doctrine was an upshot of the medieval thought but was codified and disseminated during the Queen Elizabeth's reign. Plowden (as cited in Kantorowicz, 1997, p. 7) sums up the creed as follows:

King has in him two Bodies, viz., a Body natural, and a Body politic. His Body natural (if it be considered in itself) is a Body mortal, subject to all Infirmities that come by Nature or Accident, to the Imbecility of Infancy or old Age, and to the like Defects that happen to the natural Bodies of other People. But his Body politic is a Body that cannot be seen or handled, consisting of Policy and Government, and constituted for the Direction of the People, and the Management of the public weal, and this Body is utterly void of Infancy, and old Age, and other natural Defects and Imbecilities, which the Body natural is subject to, and for this Cause, what the King does in his Body politic, cannot be frustrated by any Disability in his natural Body.

That being so, no single deed of the crowns could be vulnerable to the reprimand and censure of the subjects. Kings' exploits and undertakings, hence, represent the God's will and beyond rebuke. Plowden moves further on to elucidate how these two separate bodies can unify. He asserts that the 'body politic' embraces the 'body natural'. Body natural is lesser than body politic; however, these two bodies are indivisible since they amalgamate in 'One Person'. This Person's 'body natural' is under the supervision of the 'body politic' and, thus this same persons conducts are celestial and not prone to being annulled or disapproved by frail human beings (ibid., p. 9).

Shakespeare's play Macbeth renders a world with such a notion embedded at the center, and the king stands at the top of the hierarchical pyramid. King's force wins against any power, and any mutiny staged against him is doomed to defeat. King Duncan, in Macbeth, is Godly. He represents God's celestial power on a lower order on earth. Duncan, as a symbol of the Almighty, protects his people from the duplicity and the invasions of the sworn enemies from without. At the very outset of the play, to fulfill one of his obligations, safeguarding the subjects, King Duncan has sent his army to subdue two separate invading troops: one from Ireland spearheaded by the insurgent Macdonald, and the other is the one dispatched from Norway. Consequently, when Duncan learns about the victory of his armed forces, he shrieks: "Great happiness! " (I.2:59)

This divinity of King's identity is a 'dominant' cultural form in the world of Macbeth. Both king's right to the throne and his authority are absolute (Dutton \& Howard, 2003, p. 130). This 'absolute' right was initially a wholly positive concept - meaning perfect, complete, or unrestricted. The subjects to Duncan's sovereignty are willing to or bound by this 
dominant ideological component of the society. Some people revel in being under the jurisdiction of a supreme king who represents their God in earthly territory; but as was stated before, culture, in Williams' estimation, is not something 'given' and fixed. Though the concept of 'divine kingship' is the dominant cultural form in this society, it does not testify that some undercurrents of opposing ideologies do not roam within the borders of this same society. We can learn from Michel Foucault that "the greater the claims of divine monarchical authority, the more certain we can be that such claims were resisted or disputed." (Dutton \& Howard, 2003, p. 127) Having minor political advantage, the opposing forces mostly try to hide their intentions from the chief members of the dominant order, which hold the dominant ideologies, before coming to a certain degree of mastery and power.

Macbeth encounters the trio of witches who appear in a moor while he passes by along with Banquo, following their pitched battle. One of the witches chants: "All hail, Macbeth, that shalt be King hereafter!" (I.3:50) This mere sentence sets in motion some mental struggles inside Macbeth. Now we are at the dawn of an undercurrent tendency against the 'dominant' element in culture: divine kingship. Macbeth visits King Duncan and arranges for a festivity in his castle Inverness. He hankers after seeing him crowned but how can it come true while being fettered by the notion of the divinity of king and while King Duncan has announced his intention to name Malcolm as his legitimate heir and successor. When Macbeth sends words to his wife, Lady Macbeth, about the account of what had occurred to him recently, she does not suffer the pain of mental anguish Macbeth undergoes. She thirsts for having her husband enthroned. Nevertheless, since the dominant culture signifies the celestial character of the king and since Malcolm is the candidate, and not Macbeth, for succeeding the king, she finds no other alternative but to rebel against the dominant culture. Two explanations might suggest what Lady Macbeth does. Whether she stands against the notion of kings' divinity itself and assesses it to be senseless and without any logical stance, or else, despite accepting the notion, Lady Macbeth mounts a rebellion against God. This undercurrent of evil thoughts by Lady Macbeth starts taking root in the society.

Lady Macbeth sees Macbeth "full o' milk of human kindness" (I.5:15) and not suitable for taking 'the nearest way'. She wants Macbeth to "look like the innocent flower / But be the serpent under it." (1.5:63-4) She urges Macbeth to go 'the nearest way' that means nothing but murdering the king and blatantly violating and assaulting the 'dominant' culture. Nevertheless, since the dominant culture is not easy to challenge, they need to be completely cautious and prudent. Practically, time factor gets pivotal to pave the way for action.

Macbeth and Lady Macbeth devise plots for infringing the dominant culture but Macbeth is not sure to take issue with it. In this mutual struggle between Macbeth and his wife, Lady Macbeth is the final winner. They are determined to take some evil actions against the dominant culture that does not permit them to realize their dreams. In act II, scene II, we run into Macbeth who, while Duncan, the vice-regent of God, is asleep, stabs him to death. He hears a voice crying out: "Sleep no more, / Macbeth does murder sleep." (II.2:33-4) Storm, also, commences to rage when this deed of mere shamelessness is committed. These are the points that Shakespeare makes to conform to some of his readers' ideologies and especially that of the dominant order, which deifies the king.

At this point, Macbeth challenges the authority of the dominant culture. He calls into question the celestial identity of the king and repudiates it. From these early stages, Macbeth tries to eliminate all those who bear residual ideologies in their minds and who may develop roots and prey his mind in the coming days. Nevertheless, two of those who could take roots against Macbeth were King Duncan's sons: Malcolm and Donalbain. These two could not see themselves immune from the hazards of the evildoers, since the one, or the group, who assassinated their father, could commit the same deed to them too. Hence, Malcolm decides: "I'll to England," and Donalbain determines "To Ireland, I; our separated fortune Shall keep us both the safer." (II.3:138-40) Therefore, they both flee from the crime scene to their set destinations. In act II, scene IV, we come to know from Macduff that Macbeth has been made king by the other lords and supposed to be crowned. At act III, scene I, Macbeth ponders on the witches' prophecies and their postulation about Banquo. In a soliloquy, Macbeth contemplates that since the first prophecy has come true, the second prophecy is predictable to be materialized too. That being so, Macbeth states that "Upon my head they placed a fruitless crown / And put a barren sceptre in my gripe, / Thence to be wrench'd with an unlineal hand, / No son of mine succeeding" (III.1:63-65).

All of these concerns and terrors reveal that even King Macbeth is alarmed to the dangers of the residual elements, those who believed in the divinity of kings, in his society. Thus, very clearly Shakespeare is broadcasting signals that even in those times in which king was considered an earthly god and sacred, there were some to negate it, and hence, the culture was not fixed and firm. Unfailingly there have been individuals or groups who questioned the dominant cultures, and different dominant, residual and emergent elements call each other into question.

Macbeth arranges for another case of elimination of those who have attached themselves to the residual element: Banquo and Fleance. A gang of killers make away with Banquo at Macbeth's command but Fleance escapes through the darkness. This is a point of despair for Macbeth. Since if only Fleance had died, his crown could have been secured. He 
dejectedly expresses that "There the grown serpent lies; the worm that's fled Hath nature that in time will venom breed" (III.4:31-3). The 'worm that's fled' makes up another member leaping through the residual lane and can be in a fit state to take up arms against the king. Macbeth is well aware of this residual element.

As previously touched upon, kings were absolute in their power. But within this process of a change of the dominant point, absolute from being complete and perfect changes meaning to "too much" and consequently synonymous to 'tyrannical'. At the outset of act III, scene VI, we have a change of scene somewhere in Scotland where Lennox and one other lord discuss the recent suspicious deeds. They are suspicious about Macbeth himself as the originator of the not long past deeds of horror. The lord informs Lennox that Macduff has gone to England, where he will join Malcolm in pleading with England's King Edward for seeking aid. So the mortals who care for the previous values are getting unified and fortified as the time passes. Therefore, we are on the verge of noticing the residual elements gaining power. Members who were part of the dominant culture not long ago and are within the residual order now care for their own values. They are residual within the power boundary but not utterly inactive within and without this same border. Consequently, they arrange schemes to slaughter the one who sabotaged the dominant element in their culture, which had been established on the divinity of kings.

Finally, the war between the dominant culture and the residual one which has recently gained power breaks. The residual culture (divine kingship) vanquishes the dominant culture (kingship is not divine) and we have, at this point, the 'emergent' of another culture which inherits the cares of the one before the defeated culture. Accordingly, we observe the rise of new values and expressions in the society based on the point that king is not divine.

Another point that needs to be elaborated on is that, in Macbeth, not only the 'residual' culture but also the 'dominant' culture ruins Macbeth's prosperity and good fortune. Before Macbeth's succeeding to throne, the society was bound by the cares of the dominant culture which commanded the divinity of kings. When this 'dominant' culture collapses (the divinity of kings transgressed by Macbeth), the newly set 'dominant' culture which has been established upon violating divine kingship may not seem immune, since the king is no longer divine but liable to the dangers of the society. Macbeth himself has anticipated this previously: "...that we but teach Bloody instructions, which being taught return / To plague the inventor." (I.7:8-9) Therefore, those who were breeding 'residual' thoughts could not be afraid of the divinity of kings since the notion had been violated by the newly dominant culture itself.

Macbeth testifies to Raymond Williams' general creed that all societies are results of the struggle between the 'dominant', 'residual' and 'emergent' elements in their cultures in a very simple way. Shakespeare could plainly see the people who could not submit themselves to accepting the divine identity of the monarchs though it was dominant at the time Shakespeare wrote this piece of literary work. Macbeth, as referred to previously, was written in 1606 when James I was king of England. James I in one of his speeches in parliament asserts that:

"Kings are justly called gods, for that they exercise a manner or resemblance of divine power upon earth. For if you will consider the attributes to God, you shall see how they agree in the person of a king." (Dutton \& Howard, 2003, p. 125)

Though William Shakespeare composed Macbeth when King James I was on English throne, the work is full of implications assailing against the dominant element in their own culture, that is the divine right theory of kingship. Shakespeare could see the other currents of thought in his own society. Shakespeare saw what is currently called 'Contractual Theory'. This theory protested against the most basic beliefs of the 'Providential Theory' and argued the limited nature of kingship. The fans of this theory couldn't bear the passivity of people against the malpractice, wrongdoings and corruption of the ruling system and the 'dominant' culture. They argued that people's needs established the kingship, and the laws were of social origin and therefore preceded the king. The society changed from the divine kingship as the 'dominant' element to the point of justifying the overthrow of a rightfully enthroned king if necessary. Indeed, an attentive reading of Shakespeare's tragedies reveals that "they place as much emphasis on the duties as on the rights of kings" (Hattaway, ibid.) This is in line with what Richard Hooker (1989) in his Of the Laws of Ecclesiastical Polity highlighted:

where the law doth give dominion, who doubteth but that the king who receiveth it must hold of it and under the law according to that old axiom Attribuat rex legi quod lex attribuit ei potestatem et dominium [May the king attribute to the law that power and dominion that the law attributes to him] and again rex non debet esse sub homine, sed sub Deo et lege [the king ought not to be subject to a man but to God and the law]. (p. 40)

Furthermore, it was also a widespread doctrine that natural disasters were also other evidences of heaven's infuriation with the monarch. Therefore, there would usually be insurrections subsequent to major environmental events as the subjects observed these as proofs of heaven's discontent. Following King Duncan's murder storms began to rage 
and it was a certain proof for the protester for their future revolts against Macbeth.

\section{Conclusion}

Culture is not something 'given' but a vacillation between the dominant, emergent and residual ideologies in a society. It is supposed that in medieval era and Renaissance, especially from Henry VIII, up to almost a little after King James I the concept of kingship was divine and celestial. Nevertheless, William Shakespeare, in a time this notion was valid, though not without demur, berated the belief and associated himself to the position emphasizing also the duties of a king along with his divine right. There has been opposing forces which had challenged the 'grand narratives' of the dominant group and ideology. Macbeth attacks the dominant element in the culture, that is, the Divine Kingship. What Macbeth makes dominant is the other side of the ideology of 'divine kingship'. He actually brings to light the 'contractual theory' which stands up to regarding kings as the vice-regent of God. The moment this change transpires within the society, the residual elements of the past, still completely active in the dominant culture, commence their affairs. The active residual elements of the past exert themselves to eliminate the one who challenged their dominant culture. These residual elements unify and gain power, and in a war triumph over the dominant culture.

William Shakespeare could vividly observe these tendencies running in his age; hence he was not a mere neutral observer of the political and cultural conditions of the age. For him the idea of culture, as a phenomenon giving meaning to his life, was not a stable one; it had, in fact, a dynamic quality. From this perspective, the clash of opposing cultural elements within Macbeth signifies that despite the authority of the divine right theory of kingship, certain ideas of negation were embedded within that same culture. Shakespeare could not turn a deaf ear to other opinions which resisted against the dominant culture. Shakespeare's Macbeth, indeed, anticipated the time when 'contractual theory' became strident and absolute as the Stuart monarchy lost more and more of its power and influence in the 1630s. It developed to the point that people decided to depose the king from his throne, or even send the monarch to the guillotine.

\section{References}

Bloom, H., \& Marson, J. (2008). Bloom's Shakespeare Through the Ages: Macbeth. New York: Infobase Publishing.

Dutton, R., \& Howard, J. E. (2003). A Companion to Shakespeare's Works (Vol. II). Oxford: Blackwell.

Hadfield, A. (2004). Shakespeare and Renaissance Politics. London: Arden Shakespeare.

Hattaway, M. (2002). Tragedy and Political Authority. In The Cambridge Companion to Shakespearean Tragedy, ed. Claire McEachern (pp. 103-122). Cambridge, New york: Cambridge University Press.

Hooker, R. (1989). Of the Laws of Ecclesiastical Polity, ed. Arthur Stephen Mc-Grade. Cambridge University Press.

Kantorowicz, E. H. (1997). The King's Two Bodies: A Study in Mediaeval Political Theology. Princeton: Princeton University Press.

Shakespeare, W. (1966). Macbeth. In Shakspeare Complete works, ed. W. J. Craig (pp. 846-869). London, New York: Oxford University Press.

Williams, R. (1977). Marxism and Literature. Oxford, New York: Oxford University Press. 